\title{
Axonal Preservation in Deep Subcortical White Matter Lesions in the Ageing Brain
}

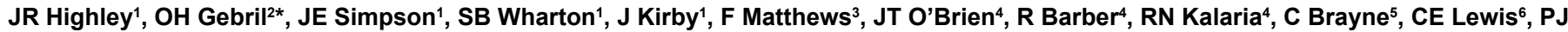 \\ Shaw ${ }^{1}$ and PG Ince ${ }^{1}$
}

${ }^{1}$ Sheffield Institute for Translational Neuroscience (SITraN), University of Sheffield, 385A Glossop Road, Sheffield, S10 2HQ, UK

${ }^{2}$ Medical Division, National Research Centre, Cairo, Egypt.

${ }^{3}$ MRC Biostatistics Unit, Institute of Public Health, Cambridge, UK

${ }^{4}$ Institute for Health and Ageing, University of Newcastle upon Tyne, UK

${ }^{5}$ Department of Public Health and Primary Care, University of Cambridge, Cambridge, UK

${ }^{6}$ Department of Infection and Immunity, University of Sheffield Medical School, Sheffield, UK

\begin{abstract}
Cerebral white matters lesions (WML) are seen in $94 \%$ of the population aged 64 and over and are associated with cognitive decline and depression. We used immunohistochemistry and stereological methods on post mortem brain samples derived from the Medical Research Council Cognitive Function and Ageing Study (MRC-CFAS) cohort to investigate the axonal density within deep subcortical lesions. There was no significant difference between the lesional and control white matter, therefore, we conclude that there is axonal preservation within these lesions that are characterized by demyelination.
\end{abstract}

Keywords: Deep subcortical lesions; Axonal density; Ageing.

\section{Introduction}

Hyperintense White matter lesions (WML) are often identified by T2-weighted magnetic resonance imaging (MRI) in periventricular or deep, subcortical regions of ageing brains. Deep subcortical lesions (DSCL) are seen in $86 \%$ of the population aged 64 and over [1] and are associated with cognitive decline and depression [2].

This laboratory has demonstrated that DSCL are associated with severe myelin loss and high levels of amoeboid, phagocytic microglia $[3,4]$.

The current study used stereological methods to investigate the hypothesis that deep subcortical white matter lesions would be characterized by axonal loss.

\section{Materials and Methods}

DSCL and non-lesional white matter were identified by MRI of post mortem brain tissue derived from the MRC-CFAS cohort [3]. Blocks of tissue were sampled from these regions, fragmented, processed and embedded in paraffin wax with random orientation. Sections $(5 \mu \mathrm{m})$ stained by immunohistochemistry for neuro filament protein, and the number of cut ends of axon within a superimposed frame were counted, according to stereological rules. From these, the length density of axons in DSCL in lesional and non-lesional tissue was calculated.

\section{Results}

The length density $\left(\mathrm{L}_{\mathrm{v}}\right)$ was calculated as 359.7 (SD 41.0$) \mathrm{m} / \mathrm{mm}^{3}$ for controls and 353.1 (SD 31.9) $\mathrm{m} / \mathrm{mm}^{3}$ for lesions. There was no significant difference between the control and lesional tissue $(\mathrm{P}=0.528)$.

\section{Conclusions}

The estimated $\mathrm{L}_{\mathrm{V}}$ of 360 and $353 \mathrm{~m} / \mathrm{mm}^{3}$ for control and lesional tissue compares well with other estimates of axonal density in white matter [5]. Surprisingly, it appears that deep subcortical white matter lesions are characterized by relative axonal preservation. This stands in interesting contrast to our existing demonstration of a loss of myelin [3]. The demonstration of relative (if not complete) axonal preservation in the context of myelin loss clearly has parallels with multiple sclerosis [6]. In this context it is interesting that microarray studies have demonstrated that both deep subcortical lesions [7] and multiple sclerosis plaques [8] occur against background field changes in the socalled 'normal appearing white matter'. Studies of gene expression in the normal appearing white matter of brains with white matter lesions stress the importance of genes involved in immune response, proteolysis, cell cycle progression and control, as well as ion transport [7].

\section{References}

1. Fernando MS Ince PG; MRC Cognitive Function and Ageing Neuropathology Study Group (2004) Vascular pathologies and cognition in a population-based cohort of elderly people. J Neurol Sci 226: 13-17.

2. Barber R, Scheltens P, Gholkar A, Ballard C, McKeith I, et al. (1999) White matter lesions on magnetic resonance imaging in dementia with Lewy bodies, Alzheimer's disease, vascular dementia, and normal aging. J Neurolo Neurosurg Psychiatry 67: 66-72.

3. Simpson JE, Fernando MS, Clark L, Ince PG, Matthews F, et al. (2007a) White matter lesions in an unselected cohort of the elderly: astrocytic, microglial and oligodendrocyte precursor cell responses. Neuropathol Appl Neurobiol 33: 410419 .

4. Simpson JE, Ince PG, Higham CE, Gelsthorpe CH, Fernando MS, et al. (2007b) Microglial activation in white matter lesions and nonlesional white matter of ageing brains. Neuropathol Appl Neurobiol 33: 670-683.

5. Tang Y, Nyengaard JR (1997) A stereological method for estimating the total length and size of myelin fibers in human brain white matter. $\mathrm{J}$ Neurosci Methods 73: 193-200.

6. Kornek B, Lassmann H (1999) Axonal pathology in multiple sclerosis. A historical note. Brain Pathol 9: 651-656.

*Corresponding author: $\mathrm{OH}$ Gebril, Medical Division, National Research Centre, Cairo, Egypt, Tel: +2 01157583452; Fax: +2 37791564, E-mail: olahossny@hotmail.com

Received March 07, 2014; Accepted March 12, 2014; Published March 17, 2014

Citation: Highley JR, Gebril OH, Simpson JE, Wharton SB, Kirby J, et al. (2014) Axonal Preservation in Deep Subcortical White Matter Lesions in the Ageing Brain. Aging Sci 2: 118. doi: 10.4172/2329-8847.1000118

Copyright: (c) 2014 Highley JR, et al. This is an open-access article distributed under the terms of the Creative Commons Attribution License, which permits unrestricted use, distribution, and reproduction in any medium, provided the original author and source are credited. 
Citation: Highley JR, Gebril OH, Simpson JE, Wharton SB, Kirby J, et al. (2014) Axonal Preservation in Deep Subcortical White Matter Lesions in the Ageing Brain. Aging Sci 2: 118. doi: 10.4172/2329-8847.1000118

Page 2 of 2

7. Simpson JE, Hosny O, Wharton SB, Heath PR., Holden H, et al.(2009) Microarray RNA expression analysis of cerebral white matter lesions reveals changes in multiple functional pathways. Stroke 40: 369-375.
8. Lindberg RL, De Groot CJ, Certa U, Ravid R, Hoffmann F, et al.(2004). Multiple sclerosis as a generalized CNS disease--comparative microarray analysis of normal appearing white matter and lesions in secondary progressive MS. J Neuroimmunol 152: 154-167. 